DOI: https://doi.org/10.31392/NZ-npu-145.2019.13

УДК [378.018.8:373.5011.3-051:796]:004.9

Назаревич В.

\title{
АКТИВІЗАЦІЯ ПІЗНАВАЛЬНОЇ ДІЯЛЬНОСТІ МАЙБУТНІХ УЧИТЕЛІВ ФІЗИЧНОЇ КУЛЬТУРИ ЗАСОБАМИ ІНТЕРАКТИВНИХ ТЕХНОЛОГІЙ
}

У статті представлений аналіз умов активізаиії пізнавальної діяльності майбутніх учителів фізичної культури на рівні інновачій, щзо стосуються організації, форм і методів навчання. Розглянуто алгоритм впровадження методів інтерактивного навчання в процесі вивчення дисципліни “Фізичне виховання”. Проаналізовано етапи впровадження активних методів навчання під час вивчення дисциплін ияиклу професійної підготовки майбутніми учителями фізичної культури. Визначено переваги та недоліки використання активних методів навчання в процесі вивчення дисциплін ициклу професійної підготовки майбутніх учителів фізичної культури.

Ключові слова: професійна підготовка; моделювання та проєктування освітнього процесу; активізачія освітнього процесу; інтерактивні методи навчання; етапи впровадження інтерактивних методів навчання.

Сучасна вища школа переживає болісний процес становлення, відходу від тотальної уніфікації та стандартизації освітнього процесу. Проблеми педагогічної інноватики висуваються на рівень пріоритетних серед проблем наукової педагогіки. Тому для вирішення педагогічних проблем характерним $\epsilon$ широкий інноваційний пошук, сфера якого носить досить масштабний характер. Це, зокрема, організаційні, функціональні та змістові перетворення. Особливого значення в сучасній педагогіці набувають технології моделювання та проєктування освітнього процесу. Рефрормування форм та методів навчання і виховання проявляється у виникненні діалогових фрорм спілкування суб'єктів освітньої діяльності, трансформації методів контролю знань і умінь студентів у самоконтроль та рейтинговий контроль.

При підготовці майбутнього вчителя фрізичної культури в якості одного 3 найважливіших виступає питання про роль дисциплін циклу професійної підготовки. Як озброїти майбутнього фрахівця поняттями з фізіологічних основ фізичної культури, вміннями застосовувати спортивний інвентар, спеціальне та допоміжне тренажерне обладнання і одночасно реалізувати методичний аспект, який би впливав на фрормування у студентів педагогічного підходу, бажання і здатності розглядати предмет що вивчається з позиції способів його викладання і з орієнтацією на школу?

Пошук умов, які б активізували пізнавальну діяльність на рівні інновацій, що стосуються організації, фрорм і методів навчання, можна сказати закономірно призвів до впровадження в освітній процес інтерактивних методів навчання.

Педагогічною наукою накопичено значний досвід щодо активізації 
навчально-пізнавальної діяльності студентів. Психологічний аспект досліджуваної проблеми глибоко розроблений у працях Л. С. Виготського, В. В. Давидова, О. М. Леонтьєва, Н. В. Менчинської, О.Г. Мороза, Л. Г. Подоляк, С. Л. Рубінштейна, В.І. Юрченка та інших. Дидактичні та методичні основи активізації пізнавальної діяльності учнів загальноосвітніх навчальних закладів наведені у працях Л. П. Арістової, Ю. К. Бабанського, В. П. Безпалька, М. А. Данилова, Л. В. Занкова, І. Лернера, В. І. Лозової, М. І. Махмутова, О. М. Матюшкіна, Д. Ф. Ніколенко, В. Оконя, І.Огороднікова, П. І. Підкасистого, О. М. Пєхоти, О.Я. Савченко, М. Н. Скаткіна, Н. Ф. Тализіної, Т. Шамової, Г. І. Щукіної, І. Ф. Харламова, І. С. Якіманської.

Метою статті $€$ аналіз можливості оптимізації процесу професійної підготовки майбутніх учителів фізичного виховання шляхом впровадження інтерактивних методів навчання, який повинен базуватись на принципах, які покладені в основу концепції системи активізації навчання і які охоплюють основні аспекти освітнього процесу, а також усі елементи педагогічної системи (викладач, студент, засоби навчання, форми навчання і т. д.).

Загальновідомо, що формування знань йде тим успішніше, чим вище активність тих, кого навчають, і це призводить не тільки до кращого розуміння, запам'ятовування, збереження і відновлення нової інформації, але й виробляє уміння застосовувати отриманні знання на практиці. Активна пізнавальна діяльність - це перш за все інтелектуальна робота, направлена на формування нових знань, які отримані на основі використання власного досвіду, співставлення, аналізу і синтезу фрактів. Включення в активність тих, кого навчають досягається тоді, коли навчання за своїм характером наближається до дослідного процесу, а творче середовище створюється за рахунок підвищеного інтересу до предмету.

Як засвідчує аналіз досвіду, активізація вивчення циклу дисциплін професійної підготовки майбутнього фахівця з фізичної культури обов'язково передбачає реалізацію принципу проблемності у навчанні, який поєднує в собі наукову проблемність з психологічною. Перший її аспект передбачає представлення змісту навчання у вигляді системи наукових проблем, а другий - акцентує увагу на необхідності створення в навчанні безперервного ланцюжка проблемних ситуацій, що викликають активну діяльність суб'єкта.

В процесі вивчення циклу дисциплін професійної підготовки майбутнього фахівця 3 фрізичної культури значна увага приділяється фрормуванню у студентів різних практичних умінь та навичок, які реалізуються через систему практичних занять. Основою ж для даних фрорм навчання слугує теоретичний матеріал, який студенти отримують на лекційних заняттях. Теоретичний матеріал займає провідну роль в освітньому процесі і повинен бути не лише проблемним і науковим за змістом, а й забезпечувати створення необхідної орієнтовної основи для наступної самостійної роботи студентів. Обов'язковим елементом системи активізації вивчення вищезгаданих дисциплін $є$ принцип єдності освітньої, виховної та розвиваючої функцій навчання, який фіксує важливі закономірні зв'язки між складовими, що входять в його назву. Їх сукупність в активному навчанні відображається в системі цілей навчання під 
час постановки дидактичних завдань. Особливу увагу, на нашу думку слід приділяти мотиваційному аспекту з самого початку вивчення змістової частини матеріалу. У вступній частині будь-якого заняття передбачається створення міцної мотиваційної основи для всього наступного вивчення теми. В цьому разі мотивація створюється не штучно а досягається природнім шляхом. Стимулювання викликається загальним проблемним орієнтуванням студентів у змісті матеріалу.

Навчально-виховний процес повинен включати поєднання індивідуальних форм роботи з колективними.

До перших можуть бути віднесені, наприклад, такі фоорми як: самостійна робота під час проведення заняття, самопідготовка і т.д.

У ході таких занять формується і збагачується індивідуальний досвід роботи. В число колективних форм входять різноманітні види аудиторних занять, методи "круглого столу", фронтальні способи виконання графічних робіт.

Вони виховують почуття колективізму, що виявляється у єдності дій та відповідальності за кінцевий результат.

Одна 3 важливих особливостей концепції інтерактивного навчання полягає в тому, що вона передбачає активну пізнавальну діяльність при будьякій формі навчання: колективній або індивідуальній. Справа тут не в організаційній формі навчання, а в організації навчання як діяльності самого студента, тобто в рівні індивідуалізації навчання, міри самостійності та активності його мислення. Навчити чого-небуть неможливо; можливо лише навчитися - це одне із вихідних положень інтерактивного навчання. Воно й складає головну суть принципу поєднання індивідуальної форми роботи 3 колективною.

Одне з перших місць серед найбільш перспективних методів навчання міцно зайняли ділові ігри. Вони використовуються для тренування, розвитку творчого мислення, формування практичних умінь і навичок, вони дозволяють стимулювати увагу і підвищувати, інтерес до занять, активізувати і загострювати сприйняття навчального матеріалу.

3 метою виявлення можливості використання даних методів в процесі вивчення циклу дисциплін професійної підготовки майбутнього фахівця 3 фізичної культури нами було зроблено аналіз відповідної науково-методичної літератури, що дозволило узагальнити інформацію про групові методи прийняття рішень та зробити деякі висновки.

Перш за все треба зазначити, що групові методи активізації допомагають у виявленні, усвідомленні і визначенні проблеми, у встановленні визначаючих фракторів і взаємозв'язку між ними, а також у вирішенні самої проблеми.

Характеризуються ці методи тим, що:

- на стадії стимулювання творчої фантазії виключають будь-який аналіз, оцінку, співставлення;

- створюють ситуацію для подання як найбільшого числа альтернативних ідей по вирішенню проблем;

- приділяють увагу всім ідеям, навіть найменш реальним; 
- попереджують відсівання нераціональних ідей шляхом їх прив'язування до нових цілей, задач або за їх допомогою сприяють вирішення початкової проблеми;

- знімають повністю або скорочують перешкоди (обмежування), які виникають при вирішенні проблеми і часто обумовлені застарілими підходами до проблеми;

- підказують як треба використовувати творчу фантазію, як її направити на розв'язання інноваційних задач, стимулюють творче мислення.

Групові методи активізації в більшій мірі використовуються в колективній роботі, і лише невелика частина їх може застосовуватись в індивідуальному порядку

Ділова гра - це активне заняття, в якому набуваються навички дій, досвіду, знання, причому дотримуються декілька умов:

- однозначно сорормульована мета і вказані способи ії досягнення;

- забезпечена наявність противника (при його відсутності роль противника виконує природа, час);

- неможна завчасно вирахувати результат і визначити переможця;

- забезпечений вірогідний вплив умов зовнішнього і внутрішнього середовища;

-є чіткі, однакові для всіх учасників правила поведінки, встановлений порядок застосування санкцій і стимулів, премій і штрафів, назначений приз переможцям;

- створені умови, за яких учасники гри не можуть ухилитися від виконання своїх обов'язків;

- забезпечений авторитетний склад суддів і арбітражного органа, рішення яких остаточні і безапеляційні для всіх виконавців.

Велике значення має контроль поетапних результатів і його наочність умови, без яких ніяке значення не буде діючим.

Які методи навчання використовують викладачі в своїй роботі?

Дослідження показали, що досить часто викладач приблизно 2/3 пояснює, ілюструє, опитує, дає завдання по зразках і лише 1/3 часу відводить на активно-пізнавальну діяльність студентів (висуває проблему, пропонує різноманітні задачі).

Ігрові заняття в процесі професійної підготовки студентів використовуються для того, щоб в умовах самостійного пошуку рішень розширити, поглибити і закріпити знання та вміння, розвинути конструктивне мислення, комунікативні здібності діяльності.

Для розвитку професійних умінь, логічного мислення, фрормування навичок вести аргументоване обґрунтування обраного варіанту рішення нами розроблена і використовується в процесі вивчення дисципліни "Фізичне виховання" ділова гра " Вправи загального розвитку та спеціально-підготовчі вправи фрутболістів". Вона імітує поширену в шкільній практиці процедуру навчання основ техніки та тактики гри у футбол.

Гра носить комплексний аналіз. Вона дозволяє змоделювати не лише процедуру навчання основ техніки та тактики гри, але і захисту прийнятого 
рішення.

Гру можна проводити в два етапи. Спочатку створені групи готують свої варіанти техніки та тактики гри, наприклад, з використанням методу “мозкового штурму”. А потім передають їх на розгляд експертів. Після їх висновків проводиться безпосередній захист проектів кожною групою.

На початку гри виступає представник від групи, який дає попередню характеристику існуючих техніки та тактики гри відзначаючи їх основні недоліки. Потім він пояснює зміст нового рішення, обґрунтовує причини вибору даного варіанту. При цьому не повинні перебільшуватись або приховуватись недоліки проекту, що захищається. Дається характеристика нової ідеї. Після цього виділяються елементи новизни. Висловлюються думки про необхідність захисту проєкту.

Всі названі етапи проходять і інші творчі групи. Лише після цього проводиться колективне обговорення проєктів, їх оцінка, визначення кращих. При необхідності даються рекомендації по доопрацюванню того чи іншого проєкту. Наприкінці гри викладач проводить її аналіз з професіональної (як голова тренерського штабу) і дидактичної (як керівник гри) точок зору.

Запровадження інтерактивних методів навчання дозволяє сформувати у студентів відповідний тип мислення, стимулює їх пізнавальну діяльність, розвиває самостійне мислення.

Процес впровадження активних методів навчання доцільно поділити на ряд етапів.

1 етап. Вивчення теорії інтерактивного навчання, опанування методикою і принципами інтерактивного навчання, практичне оволодіння методами інтерактивного навчання.

2 етап. Викладач виділяє навчальні теми, які доцільно вивчати за допомогою інтерактивних методів навчання. Як зазначалось вище, не кожну тему можна і потрібно переводити на мову інтерактивного навчання. При виборі теми і відповідного методу треба керуватися міркуванням ефективності. Наприклад, якщо використання методу аналізу конкретних ситуацій буде сприяти кращому засвоєнню теми, то можна сідати за розробку сценарію ситуації.

З етап. Викладач складає перелік методів інтерактивного навчання, якими він в достатній мірі володіє. До кожного методу добираються такі теми 3 навчальних планів, при вивченні яких потрібно використати даний метод.

4 етап. Викладач виділяє типи задач (організаційних, технічних, виховних тощо), які студенти вирішують або з якими можуть зіткнутися на своєму майбутньому робочому місці. 3 метою підготовки до ефективного вирішення задач і повинні бути відібрані відповідні методи інтерактивного навчання.

5 етап. Відбувається відбір сюжету для інтерактивних методів навчання. Сюжет - це основа майбутнього змісту занять з використанням інтерактивних методів. Вибір диктується темою заняття. Від характеру сюжету залежить напруження і гострота заняття. Він повинен бути правдоподібним і доступним для розуміння студентами, включати в себе конфлікти, проблему або задачу, розв'язання якої вимагає зусиль, повинен бути повчальним, який не залишає 
слухача байдужим ні з етичної, ні з професійної точки зору.

6 етап. На цьому етапі викладачу потрібно опанувати техніку розробки таких своєрідних сценаріїв, проблемних задач, ділових ігор, складання кросвордів і т. ін.

7 етап. Впровадження методів інтерактивного навчання у освітній процес. При цьому треба мати на увазі, що ретельна підготовка до першого заняття не дає певної гарантії його успіху: для цього викладачу потрібен досвід. Досвідчені викладачі максимум зусиль і часу витрачають на підготовку заняття 3 використанням методів інтерактивного навчання. Вона повинна носити комплексний характер: якщо залишити поза увагою хоча б один компонент, навчальний процес буде йти зі збоями.

8 етап. Підготовка студентів до колективної діяльності.

9 етап. Проведення першого заняття. Аудиторна групова робота є однією з форм цілеспрямованої колективної діяльності з усіма притаманними їй характерними рисами. Дві 3 них відіграють особливо важливу роль у підвищенні продуктивності освітнього процесу. По-перше, практичне заняття як організована взаємодія групи студентів проходить в атмосфрері певного психологічного клімату, який відображається на рівні розумової діяльності і активності кожного студента. Поділ групи на сильних і слабких, підкреслення успіхів одних і публічне акцентування уваги на невдачах інших, неправильний розподіл ролей, необ'єктивне закріплення завдань, недостатньо принциповий аналіз індивідуальних і групових робіт обов'язково приведе до порушень у міжособистісних відносинах, до руйнування зв'язків і відмови від взаємного співробітництва. Нарешті це може закінчитися певним роз'єднанням групи, втрати інтересу до навчання. Звідси виходить, що психологічний клімат у групі, особливо на першому занятті, повинен бути предметом особливої уваги викладача.

По-друге, діяльність і поведінка людини в колективі містить в собі непомітний елемент змагання. Людині властиве прагнення до змагання за кращий результат, за визнання його переваги, досвіду, знань тощо. Це прагнення закладене у соціальній природі особистості. В практикумах, вправах, діяльність студентів набуває чітко вираженого характеру інтелектуального, професійного і психологічного єднання один з одним, одного з усіма. Студенти нерідко вступають у змагання з викладачами, довіряють своєму досвіду, розраховують лише на свої сили, очікують ефекту лише від своїх рішень. Міркування викладача студенти іноді розглядають як протидію і активно шукають аргументи на захист своєї позиції.

Ефективність першого практичного заняття 3 використанням інтерактивних методів в значній мірі залежать від того, наскільки викладач продумав кожен свій крок, жест, слово, наскільки майстерно використовує елементи змагання.

10 етеп. Оцінка ефективності застосування активних методів навчання найважливіший, заключний етап загального процесу активізації занять. На скільки добре розуміють студенти навчальний матеріал, чи вміють використовувати отримані знання в практичній діяльності, чи зросла 
ініціативність, енергійність і активність студентів на заняттях, чи підвищилась самостійність і оригінальність їх суджень, поглядів, позицій і оцінок, чи оволоділи вони умінням аналізувати і оцінювати події, факти, бачити проблеми і знаходити оптимальні шляхи їх вирішення?

Як засвідчили результати дослідження, інтерактивні методи навчання дозволяють оптимально вирішувати три навчально-організаційні задачі:

- створити оптимальні умови для контролю за процесом навчання;

- забезпечити включення в активну навчальну роботу студентів з різною підготовкою і здібностями; матеріалу.

- встановити безперервний контроль за процесом засвоєння навчального

Висновки. Використання інтерактивних методів навчання може бути ефективним шляхом до оптимізації процесу професійної підготовки майбутніх учителів фрізичної культури. Але не варто забувати і про традиційні методи навчання. Переоцінка ролі активності і самостійності студентів, як засвідчує педагогічний досвід, може призвести до негативних наслідків. Не на кожному занятті можуть бути використані методи інтерактивного навчання, зважаючи на його зміст, склад навчальної групи і т.д. При відносному пріоритеті інтерактивних методів навчання на заняттях повинні займати своє місце самостійна робота з науково-технічною літературою, індивідуальна практична діяльність, інші форми та методи навчання.

Актуальними напрямками подальшої розробки окреслюваної проблеми є вивчення питання щодо можливостей використання сучасних технічних засобів в процесі впровадження методів інтерактивного навчання на різних етапах профресійної підготовки майбутніх учителів фрізичної культури.

\section{Використана література:}

1. Джуринський П. Б. Теоретичні і методичні засади підготовки майбутніх учителів фізичної культури до здоров'язбережувальної професійної діяльності : автореф. дис. ... докт. пед. наук : спец. 13.00.04. Одеса, 2013. 43 с.

2. Захаріна Є. А. Професійна підготовка майбутніх учителів фізичної культури до позакласної та позашкільної оздоровчо-виховної роботи: теорія та методика: монографія. Запоріжжя : Класичний приватний університет, 2012. 439 с.

3. Іваній І. В. Компетентнісний підхід до професійної підготовки вчителя фізичної культури. Фізичне виховання, спорт і культура здоров'я у сучасному суспільстві. 2013. № 1. С. 43-48.

4. Іванова Л. І. Теоретичні і методичні засади професійної підготовки майбутніх учителів фізичної культури до роботи з учнями з відхиленнями у стані здоров'я : автореф. дис. ... докт. пед. наук : спец. 13.00.04. Київ, 2014. 40 с.

5. Іващенко В. П., Безкопильний О. П. Теорія і методика фізичного виховання. Ч. 2. Черкаси : ЦНТЕІ, 2006. $467 \mathrm{c.}$

6. Кодимський С. С., Чайченко Н. Н. Педагогічні умови розвитку здоров'язбережувальної компетентності вчителів фізичної культури в системі післядипломної педагогічної освіти. Педагогічні науки: теорія, історія, інноващійні технології. 2013. № 8. С. 217-224.

7. Омельяненко В. Г. Здоров'язберігаюча компетентність вчителя фізичної культури. Наукові записки Тернопільського національного педагогічного університету імені Володимира Гнатюка. Серія: педагогіка. 2007. № 1. С. 7-11.

8. Сущенко Л. П. Теоретико-методологічні засади професійної підготовки майбутніх фахівців фізичного виховання та спорту у вищих навчальних закладах : автореф. дис. ... докт. пед. наук : спец. 13.00.04. Київ, 2003. 45 с. 
9. Тимошенко О.В. Теоретико-методичні засади оптимізації професійної підготовки вчителів фізичної культури у вищих навчальних закладах : автореф. дис. ... докт. пед. наук : спец. 13.00.04. Київ, 2009. 38 с.

\section{References:}

[1] Dzhurynskyi P. B. (2013). Teoretychni I metodychni zasady pidhotovky maibutnih uchyteliv fizychnoi kultury do zdoroviazberezhuvalnoi profesiinoi diialnisti. [Theoretical and methodical principles of future PE teachers training for health caring vocational activity]. Odesa, $43 \mathrm{~s}$.

[2] Zaharina Ye. A. (2013). Profesiina pidhotovka maibutnih uchyteliv fizychnoi kultury do pozaklasnoi ta pozashkilnoi ozdorovcho-vyhovnoi roboty: teoriia ta metodyka. [Vocational training of future PE teachers for extracurricular work: theory and practice]. Zaporizhzhia, $439 \mathrm{~s}$.

[3] Ivanii I. V. (2013). Kompetentnisnyi pidhid do profesiinoi pidhotovky vchytelia fizychnoi kultury. [Competence approach to vocational training of PE teacher]. Fizychne vyhovannia, sport I kultura zdorovia u suchasnomu suspilstvi. № 1, S. 43-48.

[4] Ivanova L. I. (2014). Teoretychni i metodychni zasady profesiinoi pidhotovky maibutnih uchyteliv fizychnoi kultury do roboty z uchniamy z vidhylenniamy u stani zdorovia. [Theoretical and methodical principles of vocational training of future PE teachers to work with students who have deviation in a healthy state]. Kyiv, $40 \mathrm{~s}$.

[5] Ivashchenko V. P. (2006). Teoriia I metodyka fizychnoho vykhovannia. [Theory and methods of physical education]. Cherkasy, $467 \mathrm{~s}$.

[6] Kodymskyi S. S. (2013). Pedahohichni umovy rozvytku zdoroviazberezhuvalnoi kompetentnosti vchyteliv fizychnoi kultury v systemi pisliadyplomnoi pedahohichnoi osvity. [Pedagogical conditions of the development of health care competence of PE teachers in the system of postgraduate education]. Pedahohichni nauky: teoriia, istoriia, innovatsiini tekhnolohii, № 8, S. 217-224.

[7] Omelianenko V. H. Zdoroviazberihaiucha kompetentnist vchytelia fizychnoi kultury. [Health care competence of PE teacher]. Naukovi zapysky Ternopilskoho natsionalnoho pedahohichnoho universytety imeni Volodymyra Hnatiuka. Seriia: pedahohika, № 1. S. 7-11.

[8. Sushchenko L. P. (2003). Teoretyko-metodolohichni zasady profesiinoi pidhitivky maibutnih fakhivtsiv fizychnoho vykhovannia i sportu u vyshchyh navchalnykh zakladakh. [Theoretical and methodological principles of future PE teachers vocational training in higher educational institutions]. Kyiv, $45 \mathrm{~s}$.

[9] Tymoshenko O. V. (2009). Teoretyko-metodychni zasady optymizatsii profesiinoi pidhotovky vchyteliv fizychnoi kultury u vyshchykh navchalnyh zakladakh. [Theoretical and methodical principles of optimization of PE teachers vocational training in higher educational institutions]. Kyiv, $38 \mathrm{~s}$.

\section{НАЗАРЕВИчВ. Активизиция познавательной деятельности будущих учителей физической культуры средствами интерактивных технологий. \\ В статье представленный анализ условий активизации познавательной деятельности} будуших учителей физической культуры на уровне инноваций, которые касаются организации, форм и методов обучения. Рассмотрен алгоритм внедрения методов интерактивной учебы в прочессе изучения дисчиплины “Физическое воспитание”. Проанализированы этапы внедрения активных методов обучения во время изучения дисциплин циикла профессиональной подготовки будущими учителями физической культуры. Определень преимущества и недостатки использования активных методов обучения в процессе изучения дисциплин ияикла профессиональной подготовки будущих учителей физической культуры.

Ключевые слова: профессиональная подготовка; моделирование и проектирование образовательного процесса; активизация образовательного проиесса; интерактивные методы обучения; этапы внедрения интерактивных методов обучения.

NAZAREVYCH V. Activation of cognitive practice of future physical education teachers by interactive technologies.

The article deals with the analysis of the conditions how to activate the cognitive practice of future PE teachers by innovations concerning the organization, forms and methods of teaching. During our research we found out that it is impossible to accomplish the above mentioned tasks without introducing interactive teaching methods into the educational process. Active cognitive practice is 
represented in the research as an intellectual work, aimed at the formation of new knowledge that is obtained through the use of the experience, comparison, analysis and synthesis of facts. It is substantiated that the obligatory element of the system of intensification of the study of subjects dealing with professional training of future PE teachers is the principle of unity of educational and developmental functions of teaching. It captures important regular links between the components that are included. Their totality in active learning is reflected in the system of learning goals during the formulation of didactic tasks. In the article we proved that in these conditions special attention should be paid to the motivational aspect from the very beginning of studying the content of the material. The introductory part of any lesson should provide material for the creation of a strong motivational basis for the studying of the topic. In this case, the motivation is not created artificially but naturally. The stimulation is caused by the general problem orientation of the students in the content of the material. We considered the algorithm of introducing the methods of interactive training in the process of studying the discipline "Physical Education". In particular, the tested business game "General Development Exercises and Special Preparatory Exercises for Footballers" is described. It simulates the common practice of teaching the basics of football techniques and tactics in school practice. The stages of implementation of active teaching methods in studying the subjects dealing with vocational training by the future PE teachers are analyzed. The introduction of interactive teaching methods allows students to form an appropriate type of thinking, stimulates their cognitive activity, and develops independent thinking. The advantages and disadvantages of using active teaching methods in the course of studying the subjects dealing with professional training of future PE teachers are determined.

Keywords: vocational training, modeling and designing of the educational process, activation of the educational process, interactive teaching methods, stages of implementation of interactive teaching methods.

DOI: https://doi.org/10.31392/NZ-npu-145.2019.14

УДК 378.147 : 811'27

Оршанський Л. В., Овчаренко Л. Р. ПЕДАГОГІЧНІ УМОВИ АКТИВІЗАЦІЇ
ПРОФЕСІЙНО ОРІЕНТОВАНОЇ ІНШОМОВНОЇ ПІДГОТОВКИ
МАЙБУТНІХ УЧИТЕЛІВ НЕФІЛОЛОГІЧНИХ СПЕЦІАЛЬНОСТЕЙ

У статті визначені та охарактеризовані основні педагогічні умови вдосконалення проиесу професійно орієнтованої іншомовної підготовки майбутніх учителів нефілологічних спеціальностей, зокрема: формування професійної мотивачії вивчення іноземної мови; створення міжкультурно-орієнтованого освітнього простору; реалізація міждисииплінарних зв'язків іноземної мови з соціально-гуманітарними та професійно орієнтованими навчальними дисциплінами; паритетне включення в зміст іншомовної освіти творів, щзо містяться у вітчизняній та зарубіжній культурній спадщині; використання діалогу як основного методу іншомовного навчання; урахування регіонального соиіокультурного компонента; формування елементів інформаційної культури у процесі навчання іноземної мови.

Ключові слова: іншомовна підготовка, професійно орієнтоване навчання іноземних мов, майбутні вчителі нефілологічних спеціальностей, педагогічні умови. 